\title{
IMPLIKASI TERHADAP PENGUJIAN KETETAPAN MPR/MPRS PASCA PUTUSAN MAHKAMAH KONSTITUSI DALAM RANGKA MENGAWAL TEGAKNYA KONSTITUSI NEGARA
}

\author{
Tomi Agustian \\ Fakultas Syari'ah dan Ekonomi Islam IAIN Curup \\ Email : Tomiagustian48@gmail.com
}

\begin{abstract}
This study aims: first, the decision of the Constitutional Court adjudicates and does not accept the testing of the MPR Decree, secondly, the implications of testing the MPR's Decree after the decision of the Constitutional Court. The method used in this study is normative research or library research. The results of the study obtained first, the basis of the Constitutional Court Decision according to the 1945 Constitution of 24C paragraph (1) that the Constitutional Court only has the authority to test the Law on the Basic Law and the MPR I S Decree is not included in the Constitutional Court's authority. Secondly, the implication is that there is no mechanism for testing. MPR provisions cause a legal vacuum as well as the absence of an authorized institution to test the MPR Decree (tetraa incognita)
\end{abstract}

Keywords : Implications; Constitution; Decisions

\section{ABSTRAK}

Penelitian ini bertujuan: pertama, Putusan Mahkamah Konstitusi Mengadili dan tidak menerima pengujian Ketetapan MPR, kedua, Implikasi pengujian Ketetapan MPR pasca putusan Mahkamah Konstitusi. Metode yang digunakan dalam penelitian ini yaitu penelitian normatif atau penelitian kepustakaan. Hasil dari penelitian yang didapatkan pertama, Dasar Putusan Mahkamah Konstitus menurut UUD Tahun 1945 asal 24C ayat (1) bahwa Mahkamah Konstitusi hanya memiliki Kewenangan menguji Undang-Undang Terhadap Undang-Undang Dasar dan Ketetapan MPR/S tidak masuk dalam kewenangan Mahkamah Konstitusi. Kedua, Implikasinya tidak ada mekanisme pengujian Ketetapan MPR menyebabkan terjadinya kekosongan hukum serta tidak adanya lembaga yang berwenang untuk melakukan pengujian terhadap Ketetapan MPR (tetraa incognita).

\section{Kata Kunci : Implikasi; Konstitusi; Putusan}

\section{Pendahuluan}

Perubahan Undang-Undang Dasar

Negara Republik Indonesia Tahun 1945

Pasal 1 ayat (2), kedaulatan berada ditangan

rakyat dan dilaksanakan menurut Undang-

Undang Dasar. Ketentuan pada pada Pasal 1

ayat (2) ini selanjutnya dipertegas oleh Pasal

1 ayat (3) yang menyatakan bahwa negara

Indonesia adalah Negara Hukum. Ketentuan
Konstitusional tersebut berarti bahwa sistem

ketatanegaraan Indonesia berdasarkan Undang-Undang Dasar 1945 harus berdasarkan atas prinsip kedaulatan rakyat dan prinsip Negara Hukum. Artinya dari sudut pandang konstitusional berdasarkan ketentuan Pasal 1 ayat (2), dan Pasal 1 ayat (3) UUD 1945, maka segala bentuk keputusan dan tindadakan aparatur 
penyelenggaraan pemerintahan negara harus berdasarkan atas prinsip kedaulatan rakyat dan hukum, dan tidak berdasarkan kekuasaan yang melekat pada kedudukan apartatur penyelenggara pemerintahan itu sendiri. ${ }^{1}$ Pada Undang-Undang Dasar Tahun 1945 hasil Amandemen ke empat Majelis Pemusyaratan Rakyat tidak lagi berada pada satu lembaga tinggi negara dengan demikian tidak ada lagi lembaga representasi rakyat sebagai lembaga tertinggi negara betapa hukum akan sangat menentukan dalam pelaksanaan kenegaraan.

Undang-Undang Nomor 12 Tahun 2011 sebagaimana pengganti dari UndangUndang Nomor 10 Tahun 2004 tentang Pembentukan Peraturan PerundangUndangan ditegaskan bahwa untuk mewujudkan Indonesia sebagai negara hukum maka negara berkewajiban melaksanakan pembangunan hukum nasional dalam sistem hukum nasional yang menjamin perlindungan hak dan kewajiban segenap rakyat Indonesia berdasarkan UndangUndang Dasar Negara Republik Indonesia Tahun 1945.

Ditempatkannya kembali Ketetapan MPRS dan Ketetapan MPR RI sebagai salah satu jenis Perundang-Undangan dalam hierarki Perundang-Undangan sebagai mana diatur dalam Pasal 7 ayat (1) huruf b,

\footnotetext{
${ }^{1}$ Dahlan Thaib, Ketatanegeraan Indonesia Persfektif Konstitusional, Cetakan Pertama (Yogyakarta: Total Media, 2009), hlm 26.
}

Undang-Undang Nomor 12 Tahun 2011 tentang Pembentukan Peraturan Perundangundangan ini didasarkan pada Pemikiran dari kelemahan-kelemahan yang terkandung dalam UU Nomor 10 Tahun 2004 salah satu penyempurnaan tersebut adalah penambahan Ketetapan MPR/S sebagai salah satu jenis peraturan perundang-undangan yang ditempatkan setelah UUD NRI 1945. Undang-Undang Nomor 12 Tahun 2011 tentang Pembentukan Peraturan PerundangUndangan merupakan pelaksanaan dari perintah Pasal 22A Undang-Undang Dasar Negara Republik Indonesia Tahun 1945 yang menyatakan bahwa "Ketentuan lebih lanjut mengenai tata cara pembentukan UndangUndang diatur lebih lanjut dengan Undangundang”. Namun, ruang lingkup materi muatan Undang-Undang ini diperluas tidak saja Undang-Undang tetapi mencakup pula Peraturan Peundang-Undangan lainnya, selain Undang-Undang Dasar Negara Republik Indonesia Tahun 1945 dan Ketetapan Majelis Pemusyawaratan Rakyat.

Ketetapan MPRS/MPR yang dinyatakan masih berlaku sesuai Ketetapan MPR Nomor I/MPR/2003 dan sesuai pula dengan Undang-undang Nomor 12 Tahun 2011 tentang Pembentukan Peraturan Perundang-undangan ditempatkan kembali dalam tata urut peraturan Perundangundangan berada di bawah UUD dan di atas Undang-undang/Perpu sehingga memunculkan konsekuenasi hukum dalam 
sistem Perundang-undangan kita. Kembali berlakunya Ketetapan MPR pun tidak sertamerta mengembalikan posisi MPR seperti kondisi sebelumnya, dikarenakan pada era reformasi pembuatan Tap MPR baru tidak akan seperti masa yang sebelumnya, mengingat peran pembuatan Undang-undang (legislatif) pada era reformasi diserahkan sepenuhnya kepada Presiden dan DPR.

Pada saat ini dapat dipastikan sangat banyak Peraturan Perundang-Undangan yang berlaku di negara ini, mulai yang dibuat pada masa Hindia Belanda hingga masa reformasi sekarang ini. Keberagaman itu di satu sisi dapat disambut sebagai kekayaan tetapi di sisi lain mesti disikapi secara berhati-hati sebab tidak tertutup kemungkinan menyimpan berbagai masalah. Kemungkinan tersebut dapat diperhatikan pada beberapa permohonan uji materil (judicial review) yang diajukan kepada Mahkamah Konstitusi semata-mata demi jaminan hak Konstitusional (legal standing) pemohon dan demi kepastian hukum. Dapat di pastikan judicial review tidak akan muncul jika peraturan perundang-undangan yang ada tidak bermasalah, paling tidak menurut pihak yang mengajukan judicial review ${ }^{2}$. Kenyataan tersebut di atas tampaknya menjadi alasan pembentuk Undang-Undang tentang Pembentukan Peraturan Perundang-

${ }^{2}$ Jazim Hamidi, Pembentukan Peraturan Perundang-Undangan, (Jakarta: Tatanusa, 2005), Hal. 11.
Undangan khususnya Undang-Undang Nomor 10 Tahun 2004 tentang Pembentukan Peraturan Perundang-Undangan tidak memasukkan Ketetapan Majelis Permusyawaratan Rakyat Sementara (MPRS) dan Ketetapan Majelis Permusyawaratan Rakyat Republik Indonesia (MPR RI) sebagai salah satu jenis Peraturan PerundangUndangan dalam hierarki Perundangundangan.

Mahkamah konstitusi dan Mahkamah Agung merupakan lembaga negara yang memiliki kewenangan judicial review, alasan berdirinya lembaga Mahkamah Konstitusi yang sangatlah penting. Karena landasan berdirinya Mahkamah Konstitusi dalam rangka menegakkan hukum materil dibentuk dengan fungsi sebagai berikut ${ }^{3}$ pengawal Konstitusi (the guardian of the constitution), sebagai penafsir akhir konstitusi (the final interpreter of the constitution), pengawal demokrasi (the guardian of the democracy), pelindung hak Konstitusional warga Negara (the protector of the citizen' constitutional rights) dan sebagai pelindung Hak Asasi Manusia (the protector human rights) dalam rangka mewujudkan cita negara hukum dan demokrasi Indonesia sebagaimana cita dasar bernegara bagi bangsa Indonesia. Walaupun di Indonesia sudah terdapat lembaga Mahkamah Konstitusi, namun dalam praktik menjalankan perundang-undangan masih

\footnotetext{
${ }^{3}$ Jurnal Konstitusi, Vol. IV, No. 1, Juni 2011.Hal 5
} 
terdapat pertentangan antara satu peraturan perundang-undangan dengan peraturan perundang-undangan lainnya. Hal ini mengakibatkan suatu ketidak pastian hukum dalam negara hukum yang akan menimbulkan permasalahan yang berkepanjangan. Salah satu permasalahan konstitusi di Indonesia adalah masuknya ketetapan MPR dalam jenis dan hierarki peraturan perundang-undangan.

Mahkamah Konstitusi tentu diragukan kewenangannya untuk menguji Ketetapan MPR bila dilihat dari kedudukan Tap MPR dalam hierarki Perundang-Undangan. ${ }^{4}$ Sebagaimana penulis ketahui bahwa Tap MPR telah dilakukan permohonan Judicial Review beberapa kali ke Mahkamah Konstitusi dan permohonan pengujian itu diadili tetapi permohonan para pemohon dianggap kabur dan tidak dapat diterima oleh Sidang Majelis Mahkamah Konstitusi. Contoh yang pertama atas Putusan Mahkamah Konstitusi Nomor 86/PUUXI/2013 tentang Pengujian UU Nomor 12 tahun 2011 tentang Pembentukan Peraturan Perundang-undangan. Yang mana dalam materi yang diujikan Pasal 7 ayat (1) hurup b ditempatkan Tap MPR dalam susunan Hierarki Perundang-Undangan dan tidak ada lembaga negara yang berwenang mengujinya sehingga menimbulkan tidak adanya kepastian hukum pengujian Tap MPR ini,

\footnotetext{
${ }^{4}$ Lihat, UU Nomor 12 Tahun 2011 Pasal 7 Ayat
} (1) huruf b. dan Mahkamah Konstitusi Mengadili dan dan memutuskan tidak menerima Permohonan yang diajukan oleh Viktor dan kawankawan. ${ }^{5}$ Dan putusan yang kedua, Nomor 75/PUU- XII/2014 tentang pengujian Ketetapan MPR NO. I/MPR/2013 tentang Peninjauan Terhadap Materi dan Status Hukum Tap MPR Tahun 1960 sampai 2002 terhadap Undang-Undang Dasar NRI 1945, dengan materi yang diujikan Pasal 6 angka (30) Pengujian Tap MPRS No. XXXIII/MPRS/1967 tentang pencabutan kekuasan pemerintahan dari Presiden Suekarno. ${ }^{6}$ Mahkamah Konstitusi mengadili dan tidak menerima Permohonan yang diajukan oleh Murnanda Utama dan kawankawan dari yayasan Maharya Pati, karena permohonan pemohon dianggap kabur dan Pengujian mengenai Tap MPR Nomor I/MPR/2003 tentang Peninjauan Terhadap Materi dan Status Hukum Tap MPR Tahun 1960 sampai 2002 terhadap Undang-Undang Dasar NRI 1945, dengan materi yang diujikan Pasal 6 angka (30) Pengujian Tap MPRS No. XXXIII/MPRS/1967 tentang pencabutan kekuasan pemerintahan dari Presiden Suekarno ini, adalah yang kedua kalinya dilakukan permohonan pengujian ke Mahkamah Konstitusi, karena sebelumnya perna diajukan judicial review oleh Rahmawati Soekarno Putri yaitu Putri dari

${ }^{5}$ Putusan Mahkamah Konstitusi Nomor 86/PUU$\mathrm{XI} / 2013$.

${ }^{6}$ Putusan Mahkamah Konstitusi Nomor 75/MPRS/2014. 
mantan Presiden Pertama almarhum Ir suekarno bersama Yayasan Universitas Bung Karno dengan risalah Sidang Nomor 24/PUU-XI/2013 dengan Putusan yang sama yaitu mahkamah konstitusi mengadili dan tidak menerima permohonan tersebut. ${ }^{7}$ Hal inilah yang menjadi dilema dalam sistem ketata negaraan di Indonesia, menurut Hans Kelsen hukum itu berjenjang, dan hukum yang di bawah bersumber dengan hukum di atasnya, tentu jika hukum yang di bawah bertentangan dengan hukum di atasnya tentu dapatlah hukum yang lebih rendah tersebut di batalkan atau batal demi huku, dan di Indonesia di bentuknya Mahkamah Konstitusi yang di harapkan dapat mengawal demokrasi dan melindungi hak asasi manusia, secara yuridis tidak mempunyai kewenangan menguji Ketetapan MPR tersebut.

Permasalahan yang muncul dapat penelitian ini adalah: pertama, Bagaimanakah Dasar Hukum Mahkamah Konstitusi dalam mengadili dan tidak menerima judcial review Ketetapan MPR?, kedua, Apa Implikasi Terhadap Pengujian Ketetapan MPR pasca Putusan Mahkama Konstitusi?

\section{Metode Penelitian}

Metode yang digunakan dalam penelitian ini adalah penelitian normatif atau

\footnotetext{
${ }^{7}$ Risalah Sidang Perkara Nomor 24/PUU-XI/2013.
}

penelitian kepustakaan, yang dilakukan untuk mendapatkan data primer dan sukender dengan bahan penelitian berupa dekumen, buku, artikel, hasil penelitian, dan perundang-undangan, seta pendapat ahli. Pendekatan Penelitian, dalam hal ini penulis melakukan penelitian normatif (legal risearch) yakni, pendekatan melalui Hukum Normatif atau peraturan perundang-undangan serta Putusan Mahkamah Konstitusi yang ada kaitannya dengan penelitian, selain itu menggunakan literature berupa, dekumen, buku-buku, karya ilmiah, jurnal, Pendekatan Perundang-undangan (Statute approach), Pendekatan Historis (Historical approach), Pendekatan Conseptual (conceptual aproach) dan Pendeketan Kasus (case aproach).

\section{Hasil dan Pembahasan}

Perubahan UUD 1945 melahirkan bangunan kelembagaan negara yang satu sama lain dalam posisi setara dengan saling melakukan checks and baleces dalam mewujudkan supremasi hukum dan keadilan serta menjamin dan melindungi hak asasi manusia. Kesetaraan dan kesediaan saling control inilah prinsip dari sebuah negara demokrasi dan negara hukum. ${ }^{8}$ Implikasi perubahan UUD 1945 membawa dampak yang sangat luas terhadap semua lembaga negara. Pada satu sisi, ada lembaga yang

\footnotetext{
${ }^{8}$ Martha Pigome, "Implementasi Prinsip Demokrasi Nomokrasi Dalam Struktur Ketatanegaraan Pasca Amandemen UUD 1945" Artikel dalam Jurnal Dinamika Hukum, Vol. 113, (2000), hlm. 113.
} 
mendapat proporsi baru dengan bartambahnya wewenang secara signifikan di dalam konstitusi. Sementara disisi lain, ada pula lembaga negara yang mengalami pengurangan kewenangannya dibandingan sebelum dilakukan perubahan. ${ }^{9}$ Tidak hanya itu ada juga lembaga yang hilang kewenangannya karena sudah tidak relevan lagi bagi kebutuhan penyelengaraan negara kedepan. Di antaranya implikasi perubahan UUD 1945, yang paling tampak perubahan kewenangannya adalah perubahan kedudukan dan fungsi Majelis Permusyawaratan Rakyat (MPR). ${ }^{10}$

Sebelum perubahan Undang-Undang Dasar Negara Republik Indonesia 1945, Indonesia menganut prinsip supremasi Majelis Permusyawaratan Rakyat sebagai salah satu bentuk varian sistem supremasi parlemen yang dikenal dunia. oleh karena itu, paham kedaulatan rakyat yang dianut diorganisasikan melalui pelembagaan Majelis Permusyawaratan Rakyat yang dikonstruksikan sebagai lembaga penjelmaan seluruh rakyat Indonesia yang berdaulat, yang disalurkan melalui prosedur perwakilan politik (Political representation) melalui Dewan Perwakilan rakyat, Perwakilan

\footnotetext{
${ }^{9}$ Kuntana Magnar, "Kedudukan, Tuga, fungsi dan Kewenangan Lembaga-lembaga Negara Indonesia". Artikel dalam Jurnal Ilmu hukum Litigasi, Vol 1. No. 2 Th. (2007), hlm. 25.

${ }^{10}$ R. Agung Laksono, "Dewan Perwakilan Rakyat Repoblik Indonesia Pasca Perubahan UndangUndang Dasar Negara Republik Indonesia tahun 1945", Artikel dalam Jurnal Majelis, Vol. 1 No. 1,( 2009), hlm. 48 .
}

Daerah (regional representation) melalui dewan utusan daerah, dan perwakilan fungsional (functional representation) melalui utusan golongan. Ketiganya dimaksudkan untuk menjamin agar kepentingan seluruh rakyat yang berdaulat benar-benar tercermin dalam keanggotaan Majelis Permusyawaratan Rakyat sehingga lembaga yang mempunyai kedudukan tinggi tersebut sah disebut sebagai penjelmaan seluruh rakyat. ${ }^{11}$

Dari sudut pandang yuridis ketatanegaraan pasca perubahan sistem MPR ke sistem Bikameral yang terdiri dari lembaga DPR dan DPD telah memposisikan MPR bukan lagi sebagai lembaga tertinggi negara dan pelaksana sepenuhnya kedaulatan rakyat. ${ }^{12}$ Perubahan UUD 1945 memposisikan MPR tidak berkedudukan sebagai lembaga tertinggi negara dan pemegang kedaulatan rakyat tertinggi. ${ }^{13} \mathrm{Hal}$ ini berimplikasi terhadap kewenangan MPR yang dahulu memiliki kewenangan strategis, yaitu menetapkan UUD 1945, Menetapkan GBHN, memilih presiden dan wakil presiden. Setelah amademen menjadi (1) Mengubah dan menetapkan UUD; (2) Melantik Presiden dan wakil presiden; (3) memberhentikan presiden dan wakil presiden

11 Sri Soemantri, Prosedur dan Sitem Perubahan Konstitusi, ( Bandung: P.T. Alumni 2006), hlm. 145.

${ }^{12}$ Jimly Asshiddiqie, konstitusi dan Konstitusionalisme Indonesia, (Jakarta; Konstitusi Press 2005, hlm, 168.

${ }^{13}$ Titik Triwulan Tutik, Kontruksi Hukum Tata ... Op. cit., hlm. 7. 
dalam masa jabatannya menurut UUD 1945. MPR (legislative review). ${ }^{14}$ Selanjutnya, Akibat dari ketentuan UUD NRI 1945, forum musyawarah sidang-sidang MPR keberadaan MPR dalam sistem periode 1999-2004 Menghasilkan Ketetapan ketatanegaraan menjadi tawar dan mandul, MPR No. 1/MPR/2003 tentang peninjauan termasuk produk hukum yang dihasilkan kembali terhadap materi dan status Hukum seperti Ketetapan MPR. Bahkan melalui Undang-Undang No. 10 Tahun 2004 tentang Ketetapan MPR Tahun 1960 sampai 2002. ${ }^{15}$

Kedudukan dan status hukum MPR Pembentukan Peraturan Perundangkembali memperoleh angin segar setelah undangan, telah mencabut produk hukum diundangkannya Undang-undang No. 12 MPR yang berupa Ketetepan MPR (Tap MPR) dalam hirarki peraturan perundangundangan karena MPR tidak berwenang lagi Menetapkan GBHN, kenyataan demikian semakin memarginalkan kedudukan dan status hukum dari ketetapan MPR, padahal berdasarkan aturan tambahan Pasal 1 UUD 1945 setelah perubahan menugaskan kepada MPR meninjau kembali status hukum Ketetapan MPRS/MPR upaya guna upaya menghindari ketidak pastian status Hukum Tap MPRS/MPR.

Tap MPR Nomor I/MPR/2003 tentang Peninjauan Materi Status Ketetapan MPR dari Tahun 1966 sampai dengan 2002

Sesuai dengan ketentuan hasil Tahun 2011 tentang Pembentukan Peraturan Perundang-undangan yang memberikan landasan hukum bagi keberlakuan kembali Ketetapan MPR dalam aturan hukum di Indonesia.

Berpijak pada nelusuran diatas, terlihat bahwa Tap MPR sebagaimana dimaksud oleh pasal 7 ayat (1) huruf b, Tap MPR dan MPRS sebagaimana dimaksud dalam pasal 2 dan pasal 4 Ketetapan Majelis Pemusyawaratan Rakyat Republik Indonesia No I/MPR/2003 Pada Tanggal 7 agustus 2003 tentang peninjauan terhadap materi dan status hukum ketetapan Majelis Pemusyawaratan Rakyat sementara dan Ketetapan Majelis pemusyaratan Tahun 1960 sampai dengan tahun 2002. ${ }^{16}$

perubahan UUD 1945 sebagaimana digariskan pasal 1 aturan tambahan yang memberikan tugas kepada MPR untuk melakukan peninjauan terhadap materi dan status hukum ketetapan-ketetapan MPRS dan

\footnotetext{
14 Dahlan Thaib, Ketatanegaraan Indonesia Persfektif Konstitusional, (Yogyakarta, Total Media , 2009). hlm. 242.

${ }^{15}$ Ibid., hlm 3.

16 Penjelasan Pasal 7 ayat (1) hurup b UndangUndang Nomor 12 Tahun 2011 tentang Pembentukan Peraturan Perundang-Undangan (Lembaran Negara republik Indonesia Tahun 2011 Nomor 82, Lembaran Negara republik Indonesia Nomor 5324).
} 
Dengan berpinjak dari banyak refrensi yang penulis baca dan berdasarkan pasal 2 dan 4. Tap MPR I/MPR/2003 ada sekitar 6 Ketetapan MPR yang masih berlaku hingga saat ini sebagai berikut.; ${ }^{17}$

a. Pasal 2 (3 Ketetapan) Tap MPR Nomor I/MPR/2003, Ketetapan MPR/S Republik Indonesia sebagaimana dimaksud di bawah ini dinyatakan masih tetap berlaku dengan ketentuan masing-masing.

b. Pasal 4 (11Ketetapan) Tap Nomor I/MPR/2003. Ketetapan MPR/S Republik Indonesia sebagaimana dimaksud di bawah ini tetap berlaku sampai dengan terbentuknya UndangUndang.

Berpinjak dari Penelusuran diatas , terlihat bahwa Tap MPR sebagaimana dimaksud pada Undang-Undang Nomor 12 Tahun 2011 tentang Pembentukan Peraturan Perundang-Undangan, Pasal 7 ayat (1) huruf b, hanya tersisa 6 Ketetapan masih berlaku hingga saat ini. Yaitu;

a. Pasal 2 Tap MPR Nomor I/MPR/2003

1. Tap MPR XXV/MPRS/1966 tentang pembubaran Partai Komunis Indonesia, Pernyataan sebagai organisasi terlarang diseluruh wilayah Negara Republik Indonesia bagi Partai Komunis Indonesia dan larangan setiap kegiatan untuk menyebar atau mengembangkan Faham

\footnotetext{
${ }^{17}$ Jimly Asshiddiqie, Perihal Undang-Undang, (Jakarta: Raja Grafindo Persada, 2010, hlm 44-45.
}

atau ajaran Komunis/MarxismeLeninisme, Diberlakukan kedepan dengan keadilan dan menghormati Hukum, Prinsip Demokrasi dan Hak Asasi Manusia.

2. Tap MPR Nomor XVI/MPR/1998 Tentang Politik Ekonomi dalam Rangka Demokrasi Ekonomi, tetap diberakukan dengan ketentuan Pemerintah berkewajiban mendorong keberpihakan politik ekonomi, Usaha kecil menengah, dan koperasi sebagai pilar ekonomi dalam membangkitkan terlaksananya pembangunan nasional dalam rangka demokrasi ekonomi sesuai dengan Pasal 33 UUD NRI 1945.

b. Pasal 4 (11 Ketetapan) Tap Nomor I/MPR/2003. Ketetapan MPR/S Republik Indonesia sebagaimana dimaksud di bawah ini tetap berlaku sampai dengan terbentuknya Undang-Undang.

1. Tap MPR Nomor XI/MPR/1998 tentang Penyelenggara yang Negara bersih dan Bebas Krupsi, Kolusi, dan Nepotisme tetap berlaku sampai terlaksananya seluruh ketentuan dalam keteapan tersebut. Sekerang telah terbentuk Undang-Undang tentang Pemberantasan Tindak Pidana Korupsi. Tetapi masih ada aspek yang terkait dengan Mantan Preisiden Soeharto yang belum terselesaikan hingga saat ini, sehingga ketetapan dinyatakan masih tetap berlaku. 
2. Tap MPR Nomor VI/MPR/2001 tentang Etika Kehidupan Berbangsa,

3. Tap MPR Nomor VII/MPR/2001 Tentang Visi Indonesia Masa depan.

4. Tap MPR Nomor IX/MPR/2001 tentang Pembaharuan Agraria dan Pengelolaan Sumber Daya Alam, sampai terlaksananya seluruh ketentuan dalam Ketetapan tersebut.

Sebagaimana Putusan Mahkamah Konstitusi yang mengadili dan Tidak Menerima Pengujian Tap MPR. Hal ini akan berimplikasi terhadap Tap MPR yang masih berlaku dan tidak adanya kepastian hukum dan akan menimbulkan banyaknya tuntutan Hak Konstitusional yang dilanggar terhadap tap MPR yang masih berlaku. Sampai saat ini berjumlah 6 Ketetapan dan ini akan membawah Implikasi terhadap Pengujian Tap MPR tersebut. Salah satu Implikasi yang membuat penempatan Tap MPR dalam Hierarki Undang-Undang Nomor 12 tahun 2011 tentang pembentukan Peraturan Perundang-Undangan ini menjadi dilematis adalah potensi pertentangan Tap MPR dengan Undang-Undang Dasar 1945 dan Undang-Undang di bawahnya. Adapun beberapa yang muncul akibat pertentangan ini padahal Undang-Undang Dasar Negara Republik Indonesia Tahun 1945 menjadi dasar berpijak dalam segala ketentuan Perundang-Undangan di Indonesia dan Mahkamah Konstitusi dibentuk sebagai solusi untuk lebih mewujudkan Indonesia sebagai Negara Hukum yang sesungguhnya, yaitu segala sesuatu bentuk pergaulan dalam hidup bermasyarakat berdasar atas hukum dan hukum dibentuk dengan berdasarkan pada aturan dasar filosofi bernegara, yaitu Konstitusi.

Tap MPR yang berjumlah 6 Ketetapan yang masih berlaku ini yang menjadi pertanyaan mengapa Tap MPR ini dimasukannya lagi kedalam UU No. 12 tahun 2011 tentang Pembentukan Peraturan Perundang-Undangan dalam Pasal 7 ayat (1) diatur tentang tata urutan (hierarki) peraturan perundang-undangan republik Indonesia. $^{18}$ Dengan demikian, Tap MPR/MPRS yang masih berlaku ini membawa permasalahan Implikasi yang dapat ditimbulkan terhadap berlakunya Undang-undang tersebut. Masuknya kembali ketetapan MPR dalam hirarki merupakan sebuah politik hukum yang tidak lazim ditengah wacana perbaikan sistem hukum Indonesia.

Terlebih Tap MPR diposisikan di atas Undang-undang dan dibawah Undangundang Dasar 1945 yang sudah barang tentu merupakan sebuah posisi yang dilematis. Meski demikian, keberadaan Tap MPR menurut ketentuan hukum ini masi debatable. Hal ini mengingat berdasarkan Undang-undang dasar 1945 setelah

\footnotetext{
${ }^{18}$ Republik Indonesia, Undang-Undang pembentukan Pertauran Perundang-Undangan, No. 12 Tahun 2011.
} 
amandemen kedudukan MPR tidak lagi sebagai lembaga tertinggi negara tetapi hanya sebatas lembaga tinggi negara sebagaimana lembaga-lembaga tinggi lain, hal ini menimbulkan masalah hukum menyangkut kedudukan dan status hukum dari Ketetapan MPR yang masi berlaku di Indonesia karena akan masih memungkinkan bertentangan dengan Undang-Undang dibawah dan termasuk dengan UUD 1945.

\section{Implikasi Pengujian Ketetapan MPR}

\section{Pasca Putusan Mahkamah Konstitusi}

Putusan Mahkamah Konstitusi yang mengadili dan tidak menerima beberapa kali permohonan judicial review ke Mahkamah Konstitusi berdampak kepada Keberadaan Ketetapan MPR di dalam hierarki peraturan perundang-undangan tidak ditemukan aturan atau mekanisme pengujian TAP MPR yang menyebabkan terjadinya kekosongan hukum serta tidak adanya lembaga yang berwenang untuk melakukan pengujian terhadap Ketetapan MPR, inilah yang dinamakan tetraa incognita. Sistem perundangundangan merupakan subsistem hukum nasional yang mencakup semua hasil keputusan resmi yang tertulis dari penguasa yang mengikat umum, yang secara keseluruhan dalam kerangka sistem hukum nasional.

Menurut Hans Kelsen jika norma menetapkan bahwa prilaku tertentu "seharusnya" dilakukan, dalam arti "memerintahkan" perilaku itu, maka perilaku aktualnya boleh jadi sesuai atau tidak sesuai dengan norma tersebut. ${ }^{19}$ sistem hukum akan memperoleh makna normatifnya hanya dari kaidah-kaidah lain yang lebih tinggi. Tata hukum merupakan suatu hirarki kaidahkaidah (grundnorm). Grundnorm theory atau stufenbau theory, yaitu dalil yang menganggap bahwa semua hukum itu bersumber pada satu induk. Dalam pengertian ini, setiap norma hukum "yang lebih tinggi" adalah "sumber" dari norma hukum "yang lebih rendah". 20

Demikian pula Scheltema menjelaskan bahwa asas kepastian hukum dalam negara hukum bertujuan untuk menjamin bahwa kepastian hukum terwujud dalam masyarakat. Hukum bertujuan untuk mewujudkan kepastian dalam hubungan antar-manusia, yakni menjamin prediktabilitas dan juga bertujuan untuk mencegah bahwa hak terkuat yang berlaku. ${ }^{21}$ Merujuk pada Pasal 22A Undang-Undang dasar 1945, mengamanatkan untuk membentuk undang-undang tentang tata cara pembentukan undang-undang. Dengan pendekatan normatif tersebut maka mutatis mutandis kedudukan Ketetapan MPR di bawah UUD 1945 terderogasi dengan norma organik sebagaimana Pasal 22 A Undang-

19 Ibid, hal. 19-20.

${ }^{20}$ Op. Cit. hal. 188-189.

21 B. Arief Sidharta.. Kajian Kefilsafatan tentang Negara Hukum. Jentera : Jurnal Hukum. Pusat Studi Hukum dan Kebijakan Indonesia (PSHK). 2004, Edisi 3 Tahun II. hal. 124. 
Undang Dasar 1945, sehingga menjadi koherensi norma yang memungkinkan Ketetapan MPR akan menjabarkan materi Undang-Undang 1945.

Merujuk Pasal 28 J ayat (2) UndangUndang Dasar 1945 bahwa konstitusi dapat membatasi Hak Asasi Manusia hanya dengan undang-undang dan bukan dengan produk hukum lain. Tetapi Ketetapan MPRS Nomor XXV/MPRS/1966 tentang Pembubaran Partai Komunis Indonesia (termasuk larangan paham komunis) jelas mengandung materi muatan yang jelas melakukan pembatasan Hak Asasi Manusia.

Masalah lainnnya yaitu tidak ada mekanisme pengujian terhadap Ketetapan MPR menyebabkan terjadinya kekosongan hukum serta tidak adanya lembaga yang berwenang untuk melakukan pengujian terhadap Ketetapan MPR, inilah yang dinamakan tetraa incognita. Selain itu keberadaan Ketetapan MPR telah menjadikan tidak adanya kepastian hukum dan menciderai keadilan dan hak konstitusional warga negara sebagaimana amanat Pasal 28 D Undang-Undang 1945, dengan begitu tanpa disadari telah menciderai konsepsi negara hukum dalam jaminan, pemenuhan dan perlindungan hak asasi manusia.

Sebagaimana telah di uraikan di atas bahwa hierarki peraturan adalah murni bentuk pilihan kebijakan pembentuk undangundang . namun yang di permasalahkan adalah bukan masalh salah atau benar penempatan Ketetapan MPR tersebut, namun yang menjadi permasalahannya adalah implikasi yang ditimbulkan dari Ketetapan MPR tersebut, salah satu implikasi yang membuat dilematis penempatan tersebut adalah Tap MR tersebut akan berpotensi benrtentangan dengan Undang-Undang Dasar, dan yang menjadi permasalahannya adalah DPR dan pemerintah dalam hal ini tidak mengatur pengujian ketetapan MPR tersebut, didalam Undang-Undang Nomor 12 Tahun 2011 Pasal 9 ayat (1) bila suatu Undang-Undang bertentngan dengan Undang-Undang Dasar maka yang berwengan mengujinya adalah Mahkamah Konstitusi dan ayat (2) Jika PeraturanPeraturan di bawah Undang-Undang bertentangan yang dapat mengujinya adalah Mahkamah Agung. ${ }^{22}$

Ketentuan Konstitusional tersebut berarti bahwa sistem ketatanegaraan Indonesia berdasarkan Undang-Undang Dasar 1945 harus berdasarkan atas prinsip kedaulatan rakyat dan prinsip Negara Hukum. ${ }^{23}$ Pada Undang-Undang Dasar Tahun 1945 hasil Amandemen ke empat Majelis Pemusyaratan Rakyat tidak lagi berada pada satu lembaga tinggi negara dengan demikian tidak ada lagi lembaga

\footnotetext{
${ }^{22}$ Lihat Pasal 9 ayat (1) dan ayat (2), UU Nomor 12 Tahun 2011 tentang Pembentukan Peraturan Perundang-undangan.

${ }^{23}$ Pasal 1 ayat (3) Undang-Undang Dasar Tahun 1945.
} 
representasi rakyat sebagai lembaga tertinggi negara betapa hukum akan sangat menentukan dalam pelaksanaan kenegaraan.

Undang-Undang Nomor 12 Tahun 2011 sebagaimana diubah dari UndangUndang Nomor 10 Tahun 2004 tentang Pembentukan Peraturan PerundangUndangan ditegaskan bahwa untuk mewujudkan Indonesia sebagai negara hukum maka negara berkewajiban melaksanakan pembangunan hukum nasional dalam sistem hukum nasional yang menjamin perlindungan hak dan kewajiban segenap rakyat Indonesia berdasarkan UndangUndang Dasar Negara Republik Indonesia Tahun 1945.

Ditempatkannya kembali Ketetapan MPRS dan Ketetapan MPR RI sebagai salah satu jenis Perundang-Undangan dalam hierarki Perundang-Undangan sebagai mana diatur pada Undang-Undang Nomor 12 Tahun 2011 didasarkan pada Pemikiran bahwa undang-undang tentang Pembentukan Peraturan Perundang-Undangan merupakan pelaksanaan dari perintah Pasal 22A UndangUndang Dasar Negara Republik Indonesia Tahun 1945 yang menyatakan bahwa "Ketentuan lebih lanjut mengenai tata cara pembentukan Undang-Undang diatur lebih lanjut dengan Undang-undang”. Namun, ruang lingkup materi muatan UndangUndang ini diperluas tidak saja UndangUndang tetapi mencakup pula Peraturan Perundang-Undangan lainnya, selain
Undang-Undang Dasar Negara Republik Indonesia Tahun 1945 dan Ketetapan Majelis Pemusyawaratan Rakyat.

Dari apa yang telah dikemuhkahkan diatas persoalan yang muncul adalah menyangkut materi dan status hukum dari 139 Ketetapan MPRS dan MPR, dan dari hasil tinjauan hanya ada 6 ketetapan MPRS yang masih berlaku di indonesia saat ini. karena tidak semua ketetapan MPRS dan MPR tersebut mengacuh pada tiga tugas atau kewenangan MPR sebagaimana ditetapkan dalam Undang-Undang 1945. Dan lebih lanjut untuk menghindari terjadinya kekosongan hukum, maka sebelum terbentuknya MPR yang merupakan sidang gabungan antara DPR dan DPD sejak Ketetapan MPR yang masih berlaku dan tetap berlaku atau sampai dibentuknya undang-undang baru. ${ }^{24}$

Harus diakui banyak mutiara pemikiran para negarawan kita pada masing-masing zamannya terdapat dalam ketetapan MPR dan MPRS tersebut, yang tidak sepantasnya dibuang begitu saja dari aspek hukum tata negara juga tidak layak diturunkan menjadi Undang-undang karena sebagian besar kaidah yang ada didalam Tap MPR berisi materi muatan Konstitusi atau UUD $1945 .^{25}$

\section{Penempatan Ketetapan MPRS/MPR} setingkat dibawah UUD 1945 dalam tata

${ }^{24}$ Ibid., hlm. 241

${ }^{25}$ Dahlan Thaib, Ketatanegaraan ... Op. Cit., hlm 241. 
urutan Peraturan Perundang-Undangan membawa Konsekuensi bahwa Ketetapan MPR harus selaras dengan UUD 1945. Dalam arti Ketetapan MPR tidak boleh dengan ketetntuan UUD NRI 1945, apabilah bertentangan maka ketetapan MPRS dan MPR kehilangan keabsahannya. Dalam hal muatan materi MPRS dan MPR bertentangan dengan UUD NRI 1945, tentunya dapat ketetapan tersebut dapat di uji terhadap UUD 1945 (uji konstitusional). Sebaliknya, Ketetapan MPRS dan MPR menjadi sumber dasar bagi pembentukan Peraturan Perundang-Undangan yang ada dibawahnya.

Kedudukan Tap MPRS dan MPR dengan konsekuensi yuridisnya tersebut,justru menjadi masalah karena ketidak jelasan dan inkonsistensi pengaturan dalam UU No. 12 Tahun 2011 itu sendiri. tidak adanya mekanisme pengujian Ketetapan MPRS dan MPR dan hal ini menimbulkan kekosongan pengaturan. Sedangkan dalam Pasal 9 UU No. 12 tahun 2011 terdapat pengaturan pengujian peraturan perundang-undangan, tetapi hanya sebatas undang-undang terhadap UUD 1945 yang dilakukan oleh Mahkamah Konstitusi dan Peraturan Perundang-Undangan dibawah UU terhadap UU yang dilakukan oleh Mahkamah Agung. ${ }^{26}$

Berpegang pada Argumen Ketua Sidang mahkamah Konstitusi Maria farida

\footnotetext{
${ }^{26}$ No. 12 Tahun 2011
}

secara yuridis penulis sependapat dengan pendapat bahwa Tap MPR hanya dapat dilakukan pengujian oleh MPR sendiri dengan alasan yaitu;

1. MPR melakukan pengujian Terhadap Ketetapan MPR Pasca Amandemen ke IV UUD 1945. Yaitu Tap MPR Nomor I/MPR/2003 tentang peninjauan Materi Status Ketetapan MPR/S dari Tahun 1960 sampai 2002, jadi walaupun itu di atur dalam peraturan peralihan tapi aturan itu masih tetap berlaku sampai saat ini, jadi kapanpun MPR dapat melakukan peninjauan kembali terhadap Ketetapan MPR yang masih Berlaku. Meski MPR sudah tidak memiliki kewenangan membuat GBHN terbukti MPR dapat membuat Ketetapan MPR malakukan pengujian terhadap Ketetapan itu walaupun itu merupakan aturan Tambahan UUD 1945.

2. Suatu peraturan itu hanya dapat dicabut, dirubah, atau diganti oleh peraturan yang setingkat juga atau yang lebih tinggi, dan yang hanya bisa melakukan itu hanya lembaga setingkat atau lembaga yang lebih tinggi. Kalau dikatakan yang sama, MPR mempunyai kewenangan menetapkan UUD sedangkan Mahkamah Konstitusi Putusannya hanya setingkat dengan UndangUndang jadi tidak dibenarkan Putusan mahkamah Konstitusi membatalkan atau mengganti Tap MPR yan posisinya 
diatas Undang-Undang Dasar. Dalam sesi kuliah Dr. Ni'matul Huda pernah menyampaikan permasalahan Putusan Mahkamah Konstitusi yang menyatakan Peninjuan Kembali boleh dilakukan berkali-kali sedangkan Mahkamah Agung mengeluarkan Perma(peraturan Mahkamah Agung bahwa Peninjuan kembali hanya dapat dilakukan sekali, dan Dr Ni'matul Huda menyakatan bahwa PutusanMahkamah Konstitusi setingkat dengan Undang-Undang jadi perma yang dikkeluarkan Mahkamah Agung itu menyalahi Putusan Mahkamah Konstitusi

3. Menurut asas a contrario actus bahwa suatu Undang-Undang yang tidak ada lembaga negara yang berwenang mengujinya maka dapat dikembalikan lagi kepada lembaga yang membuatnya. Jadi penulis sepakat bahwa Tap MPR yang secara yuridis tidak yang lembaga yang berwenang mengujinya maka MPR lah yang memilik kewenangan itu.

4. Penulis sepakat apa yang disampaikan Maria farida menyatakan MPR dan Menetapkan UUD jadi tentu MPR masi mempunyai Kekuasan membentuk aturan tertinggi dibandingkan Lembaga lain. Walaupun MPR bukan lagi lembaga tertinggi Negara tapi MPR memiliki kewenangan tertinggi dibandingkan lembaga Negara lain.

5. Penulis mengutif Pendapat dari Prof. Dr
Thaib dalam bukunya berjudul Ketatanegaraan Indonesia Persfektif Konstitusional, yang menyatakan apabila Tap MPR dicabut oleh Mahkamah Konstitusi kalau bertentangan dengan Undang-Undang Dasar hal ini bertentangan dengan kewenangan Mahkamah Konstitusi yang hanya berwenang menguji UU terhadap UUD tidak disebukan Tap MPR, berarti Mahkamah Konstitusi dalam sistem Hukum Tata Negara tidak mempunyai kewenangan untuk meninjau atau menguji Ketetapan MPR.

Implikasi tetrra incognita sebagai implikasi keberadaan Ketetapan MPR di dalam hierarki peraturan perundangundangan tentunya dapat diselesaikan walaupun pengujian Ketetapan MPR tidak disebutkan sebagai kewenangan Mahkamah Konstitusi, namun dimungkinkan dapat diujikan oleh MPR sendirin semata-mata untuk mengisi kekosongan hukum. Sebagaimana mengembangkan asas $a$ contrario actus suatu produk hukum yang tidak ada lembaga yang dapat mengujinya maka dapat di kembalikan kepada lembaga yang membuatnya tersebut, jadi Tap MPR dibuat oleh MPR maka MPR dapat menarik kembali ketetapan tersebut.

Menurut Jimly Asshidiqqie Ketetapan MPR/MPRS sebagai produk hukum yang mengatur (regeling) merupakan bentuk 
penafsiran dan elaborasi normatif itu diperlukan untuk melengkapi haluan-haluan negara yang terdapat dalam konstitusi tertulis yang belum lengkap itu. Dengan Negara lain, Ketetapan MPR/MPRS itu juga mempunyai nilai konstitusi atau setidaknya sebagai bentuk penafsiran atas Undang-Undang Dasar 1945 atau bahkan merupakan perubahan undang-undang Dasar dalam bentuk yang tidak resmi menurut ketentuan Pasal 37 UUD 1945. ${ }^{27}$

Keadilan hanya bisa dipahami jika ia diposisikan sebagai keadaan yang hendak di wujudkan oleh hukum. Upaya untuk mewujudkan keadilan dalam hukum tersebut merupakan proses yang dinamis yang memakan banyak waktu. Upaya ini seringkali juga didominasi oleh kekuatankekuatan yang bertarung dalam kerangka umum tatanan politik untuk mengaktualisasikannya. ${ }^{28}$ Tugas hukum ialah mewujudkan keadilan. Keadilan sebagai tujuan utama karena tiga kepentingan hidup bersama. Kepentingan hidup bersama Negara tiga nilai dasar hukum, yaitu keadilan, kemanfaatan dan kepastian hukum. ${ }^{29}$ Dalam kaitannya dengan pelaksanaan pembangunan, hukum mempunyai fungsi sebagai pemelihara dalam ketertiban dan keamanan,

\footnotetext{
${ }^{27}$ Jimly Asshiddiqie, Op. Cit, hal. 50

${ }^{28}$ Carl Joachim Friedrich Filsafat Hukum Perspektif Historis. (Bandung : Nuansa dan Nusamedia, 2004). Hal. 23.

29 Theo Huijbers. Filsafat Hukum Dalam Lintas Sejarah. (Yogyakarta: Kanisius, 1982). hal. 288298.
}

sebagai sarana pembangunan, sebagai sarana penegak keadilan dan sebagai sarana pendidikan masyarakat.

Perubahan atau pembaruan hukum melalui peraturan perundang-undangan yang lebih bercirikan sikap hidup serta karater bangsa Indonesia, tanpa mengabaikan nilainilai universal Negara 117 sebagai warga dunia, sehingga ke depan akan menjadi transformasi hukum yang lebih bersifat Indonesia atau mempunyai Negara bangsa yang positif.

Konsekuensinya suatu peraturan perundang-undangan atau peraturan hukum tertentu dapat dievaluasi atau disingkronisasikan, yaitu diharmonisasikan dengan peraturan perundang-undangan atau peraturan hukum yang lebih tinggi tingkatannya. Berdasarkan teori hierarki ini akan memudahkan untuk menemukan keseimbangan hukum dan keharmonisan hukum yang selaras dan serasi, serta kesesuaian di antara norma baik secara vertikal maupun horizontal.

Apabila diperlukan penafsiran, karena adanya keraguan dalam singkronisasi, maka untuk mendapatkan penjelasannya harus dicari pada maksud yang terdapat atau yang terkandung pada norma hukum pada tingkatan yang lebih tinggi. Penafsiran akan menelusuri hukum positif Negara sebagai 
sumber hukum positif norma-norma peraturan perundang-undangan Negara. ${ }^{30}$

Dalam Praktek dikenal, adanya tiga macam, norma hukum yang dapat diuji atau yang biasa disebut norm control mechanism. Ketiga-tiganya sama-sama merupakan bentuk norma hukum sebagai hasil dari pengambilan keputusan hukum, yaitu; (i) Keputusan Normatif yang berisi dan bersifat Pengaturan (regelling), (ii) Keputusan normatif yang berisi Penetapan Admnistratif (beshikking), dan (iii) keputusan normatif yang berisi dan bersifat penghakiman yang biasa disebut vonis. $^{31}$

Sebagaimana yang di ungkapkan Hans Kelsen norma hukum adalah suatu norma yang dibentuk oleh lembaga yang berwenang membentuknya dan norma hukum tersebut sah (valid) apabilah dibuat oleh lembaga yang berwenang dan berdasarkan norma yang lebih tinggi. Peraturan perundanganundangan yang memuat norma hukum memiliki ciri-ciri yang salah satunya adalah mempunyai kekuatan untuk mengoreksi dan memperbaiki dirinya sendiri. ${ }^{32}$

Sejalan dengan dengan itu, Maka kedua lembaga Mahkamah Konstitusi dan Mahkamah Agung tidak berwenang melakukan pengujian terhadap Tap MPRS

30 Marsilam Simanjuntak. Pandangan Negara Integralistik ( Jakarta: Temprint. 1994). hal. 27.

${ }^{31}$ Jimly asshidiqie, Hukum acara Pengujian Undang-Undang (Jakarta: Konstitusi Press, 2006), hlm 1 .

${ }^{32}$ Ridwan H.R. Hukum Administrasi Negara, (Jakarta: PT Raja Grafindo Persada, 2006), hlm 135. dan MPR. Teori yang relatif atau abstrak menuju yang kepositif dan seterusnya sampai ketingkat yang kongkrit. Prosesing tersebut tidaklah otomatis atau tidak berlaku dengan sendirinya tampah ada memprosesnya, tetapi apakah ada lembaga yang berwenang untuk melakukan prosesing tersebut. ${ }^{33}$

Disamping itu itu ketiga bentuk norma diatas dapat di uji kebenarannya melalui mekanisme pengadilan Judisial ataupun mekanisme non Judisial. Jika pengujian dilakukan oleh lembaga peradilan maka proses pengujiannya disebut dengan judisial review atau pengujian dilakukan oleh lembaga Mahkamah Konstitusi dan Mahkamah agung dan sebaliknya apabilah pengujian bukan oleh lembaga Judisial makan maka tidak disebut judisial review. ${ }^{34}$

Sebutan yang tepat tergantung pada lembaga mana yang kewenangan mengujinya toetsingrecht itu diberikan. ${ }^{35}$ Toetsingrecht atau hak menguji jika diberikan kepada parlemen sebagai legislator, maka pengujiannya disebut legislative review, demikian pula jika pengujian diberikan kepada pemerintah, maka pengujiannya disebut sebagai executive review. ${ }^{36}$

\footnotetext{
${ }^{33}$ Amiroeddin Sjarif, Perundang-undangan: Dasar, Jenis, dan Teknik membuatnya. Cet.2 (Jakarta; rineka Cipta, 1997), hlm. 12.

${ }^{34}$ Jimly ashidiqqie. Hukum acara...Op. cit., hlm. 12.

${ }^{35}$ Fatmawati, Hak Menguji (toetsingsrech) yang dimiliki hakim dalam sistem hukum Indonesia, cet. 2( Jakarta: PT Raja Grafindo Persada, 2006), hlm. 5.

${ }^{36}$ Jimly ashidiqqie. Hukum acara...Op. cit., hlm. 2.
} 
Di Indonesia sendiri sebelum mengadakan perubahan ketiga dan keempat UUD 1945, juga dianut paham legislative review. Yaitu Undang-Undang hanya dapat diuji dan diubah oleh lembaga yang membuatnya sendiri sendiri, yang menurut ketentuan Pasal 5 ayat (1) jo Pasal 20 ayat (1) sebelum perubahan, yang berwenang membentuk Undang-undang adalah Presiden dengan persetujuan Dewan Perwakilan Rakyat. $^{37}$

Dalam pengujian sejarah ketata negaraan Indonesia, khususnya perjalanan pengujian norma hukum, jauh sebeblum lahirnya Mahkamah Konstutusi, selain memberikan kewenangan kepada Mahkamah Agung , juga pernah memberikan kewenangan kepada MPR melalui Ketetapan MPR No. III/MPR/2000 menyatakan MPR berwenang menguji undang-undang terhadap UUD 1945. Dari penjelasan Pasal 5 tersebut nayatalah bahwa yang berfungsi sebagai penafsir Undang-undang Dasar (The interpreter of konstution) ialah MPR , bukan MA (Supreme Court) (Constitusional Court) atau MK. ${ }^{38}$ Dan setelah reformasi (sebelum perubahan ketiga UUD 1945) Kewenangan Menguji Konstitusional Undang-Undang diberikan kepada MPR (Majelis Pemusyawaratan Rakyat) hal ini diatur dalam

\footnotetext{
${ }^{37}$ Jimly ashidiqqie, Model-Model Pengujian Konstitusional di Berbagai Negara, Cet. 2 (Jakarta: Konstutusi Press, 2005), hlm 72.

38 Ni'matul Huda, Perkembangan Hukum Tata Negara...Op. cit., hlm 32.
}

ketetapan MPR-RI Nomor. III/MPR/2000 yang menentukan bahwa majelis inilah yang diberi tugas untuk aktif menilai dan menguji konstitusional Undang-undang. Kedua baik mekanisme pengujian oleh Presiden dan DPR maupun Pengujian oleh MPR, biasa dinamakan dengan legislative review bukan yudisial review. ${ }^{39}$

Akibat kekosongan hukum ini apakah Tap MPRS dan MPR dapat dilakukan pengujian legislative leview yang dapat dilakukan oleh MPR sendiri seperti halnya MPR pernah mengeluarkan Tap MPR No. I/MPR/2003 tentang peninjauan kembali status hukum ketetapan MPRS dan MPR tahun 1960 sampai tahun 2002.

Pandangan ini adalah mengembangkan asas a contrario actus karena menafikan produk hukum yang digunakan untuk melakukan pencabutan. Pandangan ini hanya bersikuku bahwa Tap MPR sebagai produk hukum MPR harusnya dapat di uji dan dicabut oleh MPR sendiri ketika memang tidak ada mekanisme pengujian oleh lembaga negara yang lain.

Terkait permasalahan yang telah diuraikan diatas mengenai pengujian ketetapan MPRS dan MPR, permasalahan yang paling mendasar adalah kewenangan MPR dalam melakukan legislative review Tap MPRS dan MPR yang masih berlaku dan bagaiman MPR yang selama ini sebagai

\footnotetext{
${ }^{39}$ Jimly ashidiqqie, Model-Model Pengujian...Op. cit., hlm 73.
} 
lembaga Legislatif ditingkat pusat diberikan kewenangan menguji kembali Ketetapan Majelis Permusyawaran Rakyat Sementara atau Ketetapan Majelis Permusyawaran Rakyat Republik Indonesia terhadap Undang-Undang Dasar.

\section{Penutup}

Implikasi yang ditimbulkan ole Putusan Mahkamah Konstitusi yang mengadili dan tidak menerima Permohonan judicial review adalah: berdampak kepada Keberadaan Ketetapan MPR di dalam hierarki peraturan perundang-undangan tidak ditemukan aturan atau mekanisme pengujian TAP MPR yang menyebabkan terjadinya kekosongan hukum serta tidak adanya lembaga yang berwenang untuk melakukan pengujian terhadap Ketetapan MPR, inilah yang dinamakan tetraa incognita. Sistem perundangundangan merupakan subsistem hukum nasional yang mencakup semua hasil keputusan resmi yang tertulis dari penguasa yang mengikat umum, yang secara keseluruhan dalam kerangka sistem hukum nasional.

Selain itu keberadaan Ketetapan MPR telah menjadikan tidak adanya kepastian hukum dan menciderai keadilan dan hak konstitusional warga negara sebagaimana amanat Pasal 28 D Undang-Undang 1945, dengan begitu tanpa disadari telah menciderai konsepsi negara hukum dalam jaminan, pemenuhan dan perlindungan hak asasi manusia.
Akibat kekosongan hukum ini apakah Tap MPRS dan MPR dapat dilakukan pengujian legislative leview yang dapat dilakukan oleh MPR sendiri seperti halnya MPR pernah mengeluarkan Tap MPR No. I/MPR/2003 tentang peninjauan kembali status hukum ketetapan MPRS dan MPR tahun 1960 sampai tahun 2002.

Pandangan ini adalah mengembangkan asas a contrario actus karena menafikan produk hukum yang digunakan untuk melakukan pencabutan. Pandangan ini hanya bersikuku bahwa Tap MPR sebagai produk hukum MPR harusnya dapat di uji dan dicabut oleh MPR sendiri ketika memang tidak ada mekanisme pengujian oleh lembaga negara yang lain.

\section{Daftar Pustaka}

AttaMimi, A. Hamid, (1990), Peranan Keputusan Presiden RI dalam Penyelenggaraan pemerintahan Negara Suatu Studi Analisis Mengenai Keputusan Presiden yang Berfungsi Pengaturan dalam Kurun Waktu Pelita $i$-iv ( Disertasi ) Fakultas Pasca Sarjana Universitas Indonesia.

Fatmawati, (2006), Hak Menguji (toetsingsrecht) Yang dimiliki hakim dalam Sistem Hukum Indonesia, Cet.2, Jakarta, P.T. Raja grafindo.

Hamidi, Jazim, Pembentukan Peraturan Perundang-Undangan,

(Jakarta: Tatanusa, 2005),

Huda, Ni'matul, (2014), Perkembangan Hukum Tata Negara Perdebatan \& Gagasan Penyempurnaan, Cet. 1, Yogyakarta: FH UII Press. 
(2009). Hukum Tata Negara Indonesia, Jakarta. Raja Grafindo Persada.

(2014). Perkembangan Hukum Tata Negara, Yogyakarta, FH UII Press.

Huijbers, Theo, (1982), Filsafat Hukum Dalam Lintas Sejarah, Yogyakarta: Kanisius.

H.R, Ridwan, (2006), Hukum Administrasi Negara, Jakarta: PT Raja Grafindo Persada.

Jimly Asshiddiqie, (2010), Perihal UndangUndang, (Jakarta: Raja Grafindo Persada.

(2005), Konstitusi dan Konstitusionalisme Indonesia, Jakarta, Konstitusi Press.

(2006), Hukum Acara Pengujian Undang-Undang, Jakarta, konstitusi Press.

------, (2005), Model-Model Pengujian Konstitusional di Berbagai Negara, Cet. 2. Jakarta: Konstutusi Press.

Joachim, Carl, (2004), Friedrich Filsafat Hukum Perspektif Historis, Bandung: Nuansa dan Nusamedia.

Kelsen, Hans, (2009), teori Umum Tentang Hukum dan Negara Judul Aslinya ( Theory Of Law and State) Diterjemahkan Rasul Muttakin. Bandung : Nusa Media.

Mahfud, Mohamad, MD. (2010). Konstitusi dan Hukum dalam Kontroversi Isu, Jakarta: Raja Grafindo.

Nasriyah Riri, (2007). MPR RI Kajian Terhadap Produk Hukum dan Prospek di Masa Depan, Yogyakarta, UII Press.

Ridwan HR. (2010). Hukum Administrasi Neagara Edisi Revisi, Jakarta, RajaGrafindo Persada.
Salim, Hs dan Erlies Septiana Nurbani, (2013). Penerapan Teori Hukum Pada Tesis dan Dosertasi, Jakarta, Raja Grafindo Persada.

Simanjuntak, Marsilam, (1994). Pandangan Negara Integralistik, Jakarta: Temprint.

Sjarif, Amiroeddin, (1997). Perundangundangan: Dasar, Jenis, dan Teknik membuatnya. Cet.2, Jakarta: rineka Cipta.

Soemantri, Sri, (2006). Prosedur dan Sistem Perubahan Konstitusi, Bandung, P.T Alumni,.

Siahaan, Maruarar, (2012). Hukum Acara Mahkamah Konstitusi Republik Indonesia, Jakarta: Sinar Grafika.

Thaib, Dahlan, (2009). Ketatanegaraan Indonesia Persfektif Konstitusional, Yogyakarta, Total Media.

Tutik, Titik Triwulan, (2010). Konstruksi Hukum Tata Negara Indonesia Pasca Amandemen UUD 1945, Jakarta, Kencana Prenada Media Group.

\section{Jurnal dan Sumber Lainnya}

Ateng Syafrudin, (2000). Menuju Penyelenggaraan Pemerintahan Negara yang Bersih dan Bertanggung Jawab, Jurnal Pro Justisia Edisi IV, Bandung, Universitas Parahyangan, 2000.

Agung, R. Laksono, (2009). "Dewan Perwakilan Rakyat Repoblik Indonesia Pasca Perubahan Undang-Undang Dasar Negara Republik Indonesia tahun 1945", Artikel dalam Jurnal Majelis, Vol. 1 No. 1.

Magnar, Kuntana. (2007). "Kedudukan, Tuga, fungsi dan Kewenangan Lembaga-lembaga Negara Indonesia". Artikel dalam Jurnal Ilmu hukum Litigasi, Vol 1. No. 2 Th. (2007), 
Martha Pigome, (2000). "Implementasi Prinsip Demokrasi Nomokrasi Dalam Struktur Ketatanegaraan Pasca Amandemen UUD 1945" Artikel dalam Jurnal Dinamika Hukum, Vol. 113.

Atta Mimi A.H.S., (1990). Peraturan Keputusan Presiden RI dalam Penyelenggaraan pemerintahan Negara Suatu Studi Analisis Mengenai Keputusan Presiden yang Berfungsi Pengaturan dalam Kurun Waktu Pelita i-iv ( Disertasi ) Fakultas Pasca Sarjana Universitas Indonesia. 